\title{
Kainate Receptors in the Rat Hippocampus: A Distribution and Time Course of Changes in Response to Unilateral Lesions of the Entorhinal Cortex
}

\author{
Jolanta Uras, ${ }^{1}$ Daniel T. Monaghan,, ${ }^{2, a}$ and Carl W. Cotman ${ }^{1}$ \\ Departments of ${ }^{1}$ Psychobiology and ${ }^{2}$ Surgery, University of California, Irvine, California 92717
}

The response of kainate receptors to deafferentation and subsequent reinnervation following unilateral entorhinal cortex lesions was studied in the rat hippocampus using quantltative in vitro autoradiography. The binding levels of [ ${ }^{3} \mathrm{H}$ ]kainic acid (KA) and changes in the distribution of KA sites were investigated in the dentate gyrus molecular layer (ML) and in various terminal zones in the CA1 field at 1, 3, $7,14,21,30$, and $60 \mathrm{~d}$ postlesion. The data from both the ipsilateral and contralateral hippocampus were compared with those from unoperated controls.

The first changes in KA receptor distribution were observed $21 \mathrm{~d}$ postlesion when the dense band of KA receptors occupying the inner one-third of the ML expanded into the denervated outer two-thirds of the ipsilateral ML. The spreading of the KA receptor field into previously unoccupied zones continued 30 and $60 \mathrm{~d}$ postlesion. At these time points, the zone enriched in [ $\left.{ }^{3} \mathrm{H}\right] \mathrm{KA}$ binding sites became significantly (on average $50 \%$ ) wider than in unoperated controls. No changes were observed in either the distribution or binding levels in other hippocampal areas or in the contralateral hippocampus at any studied time point. Saturation analysis of binding in the ipsilateral ML $60 \mathrm{~d}$ postlesion revealed changes in the maximum number of receptor sites $\left(B_{\max }\right)$ without changes in KA receptor affinity $\left(K_{\mathrm{d}}\right)$. The data suggest that the elevation of the $\left[{ }^{3} \mathrm{H}\right] \mathrm{KA}$ binding in the outer two-thirds of the ML reflects an increase in the number of both low and high affinity receptor binding sites.

The pattern of KA receptor redistribution was similar to the well-characterized pattern of sprouting of commissural/ associational systems from the inner one-third into the outer two-thirds of the ML after entorhinal lesions (Zimmer, 1973; Lynch et al., 1975). This supports the hypothesis (Geddes et al., 1985) that the KA receptor response observed in the present study reflects postlesion reorganization of inputs within the denervated ML and may be relevant to functional recovery of the damaged circuits.

\footnotetext{
Received Dec. 5, 1989; revised March 2, 1990; accepted March 15, 1990.

This work was supported by American Health Assistance Foundation Grant, ADRDA Grant II-86-102, and Leadership and Excellence in Alzheimer's Disease Grant (AGO 7918). We wish to thank Andrea Walencewic 2 for excellent technical assistance on the saturation binding experiments. We also thank Dr. Ann Clark and Jennifer Kahle for helpful comments on the manuscript.

Correspondence should be addressed to Dr. Jolanta Ukas, Department of Psychobiology, University of California, Irvine, CA 92717.

a Present address: Department of Pharmacology, University of Nebraska Medical Center, 42nd Dewy Avenue, Omaha, NE 68105.

Copyright (C) 1990 Society for Neuroscience $0270-6474 / 90 / 072352-11 \$ 03.00 / 0$
}

Kainic acid (KA) is an excitatory and neurotoxic analog of glutamate (Olney et al., 1974) which appears to bind to a distinct class of excitatory amino acid (EAA) receptors in the CNS of rat and other species (Henke et al., 1981; Monaghan and Cotman, 1982; Unnerstall and Wamsley, 1983; Monaghan et al., 1985), including humans (Geddes et al., 1985; Tremblay et al., 1985; Cowburn et al., 1989). KA binding sites are enriched in synaptic junctions (Foster et al., 1981) and there is a relatively good correlation between the density of these receptors and susceptibility of neurons to the toxic effects of KA (see references in Coyle, 1983).

In the hippocampus, KA receptors are distributed heterogeneously. Autoradiographic binding studies using $\left[{ }^{3} \mathrm{H}\right] \mathrm{KA}$ as a ligand reveal the highest concentration of binding sites in the terminal field of mossy fibers (stratum lucidum of CA3) and the inner one-third of the dentate gyrus molecular layer (ML). Other hippocampal areas exhibit moderate and low levels of receptor density (Foster et al., 1981; Monaghan and Cotman, 1982).

Lesions of the entorhinal cortex, which destroy the glutamateusing excitatory projection to the hippocampus (White et al., 1977; Cotman and Nadler, 1981; Fonnum, 1984), remove about $90 \%$ of the synapses in the outer two-thirds of the MI. (Hoff et al., 1982b; Steward and Vinsant, 1983). The damage to the entorhinal input is known to trigger complex sprouting responses in the denervated ML of the dentate gyrus from several different surviving afferent systems (for review, see Cotman and Nadler, 1978). For example, the commissural and associational (C/A) system which normally terminates in the inner one-third of the ML penetrates into the outer two-thirds of the ML after a unilateral lesion of the entorhinal cortex (Zimmer, 1973; Lynch et al., 1976).

It seems quite possible that the postinjury anatomical reorganization of inputs and functional stabilization are accompanied by changes in EAA receptors. Our previous study (Ulas et al., 1990) has shown that NMDA and quisqualate receptors exhibit plastic responses to entorhinal lesions. No systematic investigations, however, have been performed that fully elucidate the response of kainate receptors to deafferentation and reinnervation. An initial study by Geddes and colleagues (1985) showed that the reorganization of inputs in rat hippocampus following a lesion of the entorhinal cortex may be accompanied by expansion of the dense KA binding zone in the inner onethird of the ML into the outer $2 / 3$ of the ML. Similar changes in KA receptor distribution have been observed in human hippocampi obtained from Alzheimer's patients (Geddes et al., 1985; Geddes and Cotman, 1986), in which severe neuronal degeneration and cell loss in the entorhinal cortex are common 
(Hyman et al., 1986). These findings support earlier suggestions that an animal entorhinal lesion paradigm is a promising model in the search for mechanisms underlying the changes obscrved in Alzheimer's disease.

The present quantitative autoradiographic study examined changes in $\mathrm{KA}$ receptor binding in the $\mathrm{ML}$ of the rat dentate gyrus following unilateral lesions of the entorhinal cortex. The time course of receptor changes was analyzed separately in the outer two-thirds and inner one-third of the ML to correlate the response of KA receptors with postlesion sprouting and synaptic reorganization within the $\mathrm{ML}$. Several reasons, including the existence of a small projection from the entorhinal cortex to the contralateral hippocampus (Goldowitz et al., 1975; Zimmer and Hjorth-Simonsen, 1975), pronounced synapse turnover in the contralateral dentate gyrus after unilateral entorhinal lesions (Hoff et al., 1981), and contralateral responses to entorhinal lesions of NMDA receptors (Ulas et al., 1990), prompted our study of both the ipsilateral and the contralateral hippocampus.

\section{Materials and Methods}

Surgery. Male Sprague-Dawley rats (250-320 gm) were used in this study. Unilateral electrolytic lesions of the entorhinal cortex were performed as previously described (Scheff et al., 1980) and rats were allowed to survive for $1(n=3), 3(n=3), 7(n=4), 14(n=3), 21(n=3), 30$ $(n=3)$, or $60(n=7)$ days after surgery. A control group of unoperated animals with the same number of subjects was included at each time point. Rats were killed by decapitation and the brains were removed rapidly, frozen in powdered dry ice, and stored at $-70^{\circ} \mathrm{C}$ until used. Lesion placement was verified by visual inspection and acetylcholinesterase histochemistry (Naik, 1963).

Autoradiography. Six-micrometer coronal brain sections were cut in a cryostat and thaw-mounted onto gelatin-subbed microscope slides. The tissue sections were stored at $-20^{\circ} \mathrm{C}$ overnight. Binding to KA sites was performed according to the previously published method (Geddes and Cotman, 1986). Sections were preincubated at $30^{\circ} \mathrm{C}$ for $10 \mathrm{~min}$ in $50 \mathrm{~mm}$ Tris-citrate buffer, $\mathrm{pH} 7.0$, to remove endogenous glutamate, aspartate, and ions. This was followed by incubation with $50 \mathrm{nM}\left[{ }^{3} \mathrm{H}\right] \mathrm{KA}$ $\left(60 \mathrm{Ci} / \mathrm{mmol}, \mathrm{NEN}\right.$, Boston, MA) for $30 \mathrm{~min}$ at $0^{\circ} \mathrm{C}$. Saturation analysis of $\left[{ }^{3} \mathrm{H}\right] \mathrm{KA}$ binding was performed using 10 different ligand concentrations, ranging between 0.9 and $400 \mathrm{~nm}$, in the presence or absence of $10 \mathrm{~mm} \mathrm{Ca}$-acelate to assess KA receptor high and low affinity binding sites. Nonspecific binding was determined with $100 \mu \mathrm{M} \mathrm{KA}$ present in the incubation mixture. Incubation was terminated by rinsing sections in a series of 4 coplin jars containing ice-cold buffer for a total of 28 sec. The sections were then dried by a stream of air and placed in $\mathrm{X}$-ray cassettes against tritium-sensitive film ( ${ }^{3} \mathrm{H}$-Hyperfilm, Amersham, Arlington, IL) along with ${ }^{3} \mathrm{H}$-standards (Amersham, Arlington, IL) for 4 weeks at $4^{\circ} \mathrm{C}$.

Quantitative analysis of autoradingrams was performed using a MCID image analyzer (Imaging Research, St. Catherines, Ontario, Canada). For each hippocampal region investigated, measurements were taken throughout the entire extent of the layer to ensure a representative sample. At least 6 readings per single brain section were made for each region studied. The binding data for the ML of the dentate gyrus (the outer two-thirds and inner one-third of the ML) represent values obtained from direct measurements of binding levels in these areas without correction of binding values for shrinkage of the ML evoked by entorhinal lesions. For each individual animal, measurements from 3 brain sections were analyzed to obtain a mean value. Measurements from the ipsilateral and contralateral hippocampus were always compared with those from sections of hippocampi of unoperated, control rats placed on the same microscope slides. Analysis of saturation binding data was performed using the computer program FBDA/I IGAND (McPherson, 1985).

The changes in distribution profile of the $\left[{ }^{3} \mathrm{H}\right] \mathrm{KA}$ binding sites within the dentate gyrus ML were also analyzed. The receptor density in a given area was plotted as a function of distance from the granule cell layer. Measurements were taken from 2 different regions of the dorsal blade dentate gyrus ML and 1 region of the ventral blade ML (see legend to Fig. 4).

Statistics. Statistical analyses were performed using Student's $t$-test (2-tailed) or 1-way analysis of variance (ANOVA). When ANOVA was applied, differences between individual groups were examined using Scheffe $F$-test.

\section{Results}

\section{$\left[{ }^{3} \mathrm{H}\right] \mathrm{KA}$ binding in normal hippocampus}

Hippocampal [ $\left.{ }^{3} \mathrm{H}\right] \mathrm{KA}$ binding sites were primarily concentrated in 2 laminae: the inner onc-third of the $\mathrm{ML}-$ the $\mathrm{C} / \mathrm{A}$ terminal field (dorsal blade of the dentate gyrus: $0.746 \pm 0.065 \mathrm{pmol} /$ mg protein; ventral blade of the dentate gyrus: $0.794 \pm 0.068$, mean \pm SEM), and the stratum lucidum $(1.992 \pm 0.153 \mathrm{pmol} /$ $\mathrm{mg}$ protein). This finding is in agreement with our previous studies (Monaghan and Cotman, 1982). The binding levels in other hippocampal areas were significantly lower: stratum radiatum of CAl $(0.223 \pm 0.078 \mathrm{pmol} / \mathrm{mg}$ protein $)$, stratum oriens of CA1 $(0.237 \pm 0.079 \mathrm{pmol} / \mathrm{mg}$ protein $)$, and the outer two-thirds of the ML - the terminal field of input from the entorhinal cortex (dorsal blade: $0.283 \pm 0.071 \mathrm{pmol} / \mathrm{mg}$ protein, ventral blade: $0.355 \pm 0.070$ ). The $\left[{ }^{3} \mathrm{H}\right] \mathrm{KA}$ binding in the ventral blade was consistently higher than that in the dorsal blade.

\section{Time course of changes in $\left[{ }^{3} \mathrm{H}\right] \mathrm{KA}$ binding in the ipsilateral and contralateral hippocampus}

There was no statistically significant change in the level of $\left[{ }^{3} \mathrm{H}\right] \mathrm{KA}$ binding in either the ipsilateral or contralateral hippocampus in the first $21 \mathrm{~d}$ after unilateral lesions of the entorhinal cortex (Figs. 1 and 2, data for stratum oriens and stratum radiatum are not shown). Thirty days after the lesion, however, a significant increase in $\left[{ }^{3} \mathrm{H}\right] \mathrm{KA}$ binding was observed in the outer twothirds of the ML in both the dorsal and ventral blade of the ipsilateral dentate gyrus, where binding levels reached $133 \%(p$ $=0.05)$ and $154 \%(p<0.05)$ of control levels, respectively. Slightly elevated binding levels ( $112 \%$ of control, not significant statistically) were also detected in the inner one-third of the ML of the ventral blade (Fig. 2). No changes in binding were found at this time point in the ipsilateral stratum oriens $(94 \pm 6 \%$ of control, mean $\pm \mathrm{SEM}$ ), stratum radiatum ( $94 \pm 4 \%$ ), stratum lucidum $(99 \pm 3 \%)$, or in any of the investigated areas in the contralateral hippocampus. The increase in $\left[{ }^{3} \mathrm{H}\right] \mathrm{KA}$ binding was even more striking $60 \mathrm{~d}$ postlesion (Figs. 1 and 2). The binding in the dorsal blade of the ipsilateral dentate gyrus reached $147 \%$ of control $(p<0.001)$ in the outer two-thirds of the ML and $116 \%(p<0.001)$ in the inner one-third of the ML; and in the ventral blade, $174 \%(p<0.001)$ in the outer two-thirds of the ML and $119 \%(p<0.001)$ in the inner one-third of the ML. Binding in other areas of ipsilateral hippocampus did not differ from control levels and was $97 \pm 2 \%$ in stratum oriens, $95 \pm$ $3 \%$ in stratum radiatum, and $100 \pm 3 \%$ in stratum lucidum. Similarly, no significant binding changes were found in the contralateral hippocampus at $60 \mathrm{~d}$ postlesion (dorsal blade: outer two-thirds of the ML, $114 \pm 5 \%$; inner one-third of the ML, $105 \pm 2 \%$; ventral blade: outer two-thirds of the ML, $110 \pm$ $4 \%$; inner one-third of the ML, $105 \pm 2 \%$; stratum lucidum, $100 \pm 4 \% ;$ stratum oriens, $104 \pm 2 \%$; stratum radiatum, $96 \pm$ $7 \%)$.

To detect the relative difference between the effect of the lesion on the operated and unoperated side, the ratio of $\left[{ }^{3} \mathrm{H}\right] \mathrm{KA}$ binding levels in the ipsilateral vs contralateral hippocampus was calculated (Fig. 3). The biggest differences in binding levels were found for the outer two-thirds of the ML in the ventral blade $30 \mathrm{~d}(1.51 \pm 0.17, p<0.01)$ and $60 \mathrm{~d}(1.58 \pm 0.14, p<0.001)$ postlesion. Analogous but smaller differences were observed for 


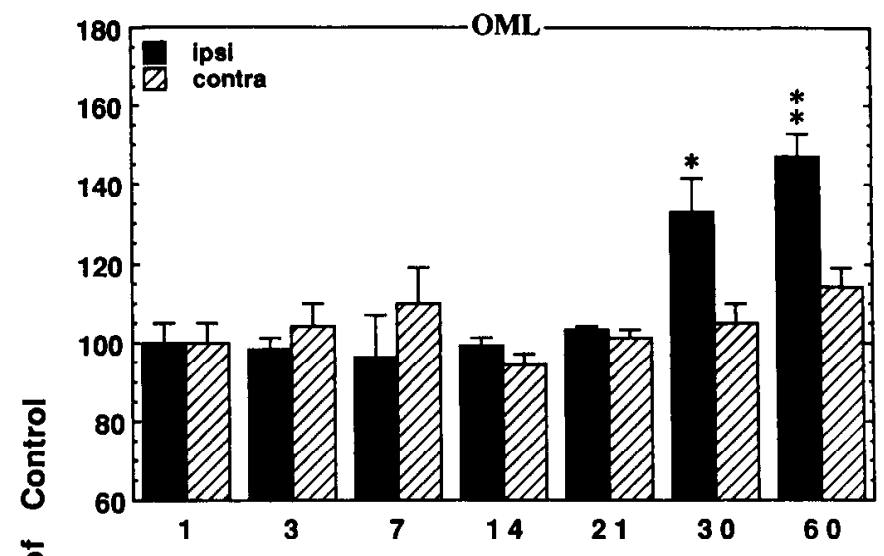

\%

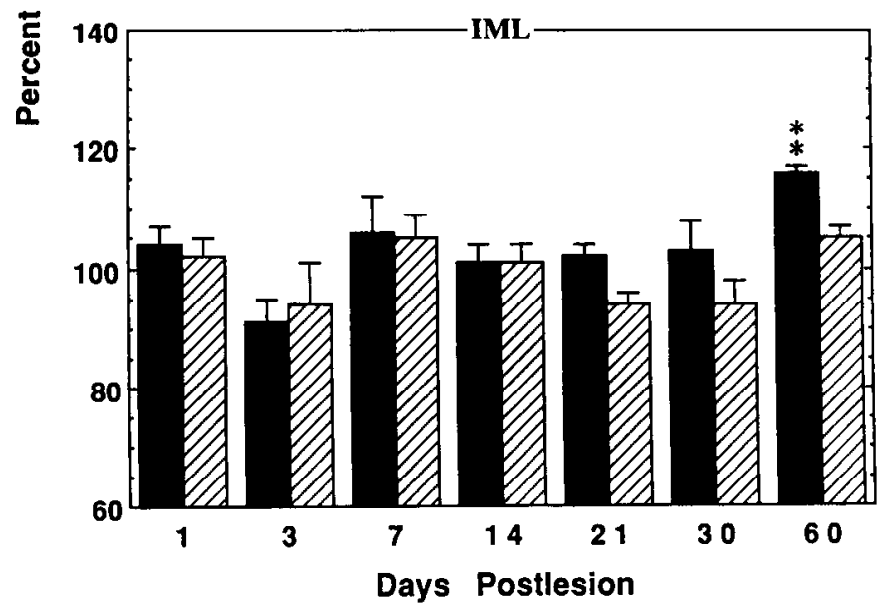

Figure 1. $\left[{ }^{3} \mathrm{H}\right] \mathrm{KA}$ binding in the dorsal blade of the ipsilateral and contralateral dentate gyrus at different postlesion times. The binding in the outer two-thirds $(O M L)$ and inner one-third $(I M L)$ of the ipsilateral and contralateral dentate gyrus ML was determined as described in Materials and Methods using $50 \mathrm{nM}\left[{ }^{3} \mathrm{H}\right] \mathrm{KA}$. Specific binding accounted for about $90-95 \%$ of total binding. Data (mean \pm SEM) are expressed as a percentage of binding relative to unoperated controls of the same age. Significantly different from control: ${ }^{*} p<0.05{ }^{* *} p<0.001$ (Student's $t$-test, 2-tailed).

the outer two-thirds of the ML in the dorsal blade: $1.26 \pm 0.11$ $(p<0.05)$ and $1.29 \pm 0.07(p<0.001)$ at 30 and $60 \mathrm{~d}$, respectively. For the dorsal blade inner ML these values were: $1.09 \pm 0.07(30 \mathrm{~d})$ and $1.10 \pm 0.02(p<0.001,60 \mathrm{~d})$; for the ventral blade inner one-third of the ML: $1.10 \pm 0.07$ and 1.13 $\pm 0.02(p<0.001)$ at 30 and $60 \mathrm{~d}$, respectively. No ipsi/contra changes were found for the stratum lucidum (Fig. 3), stratum oriens, or stratum radiatum at any investigated time point (data not shown).

\section{Changes in the distribution profile of $\left[{ }^{3} H\right] K A$ binding sites}

In order to further evaluate the character of postlesion changes in the KA receptor, the level of binding was analyzed separately in 2 regions of the ML of the dorsal blade and in 1 region of the ML of the ventral blade (Fig. 4). Binding density profiles in unoperated control rats were compared with those observed in lesioned animals.

One day after a unilateral entorhinal lesion the distribution profile of $\left[{ }^{3} \mathrm{H}\right] \mathrm{KA}$ binding sites in the ipsilateral dentate gyrus ML was similar to the pattern of binding in the contralateral ML (Fig. 5) and in the dentate gyrus ML from unoperated con-

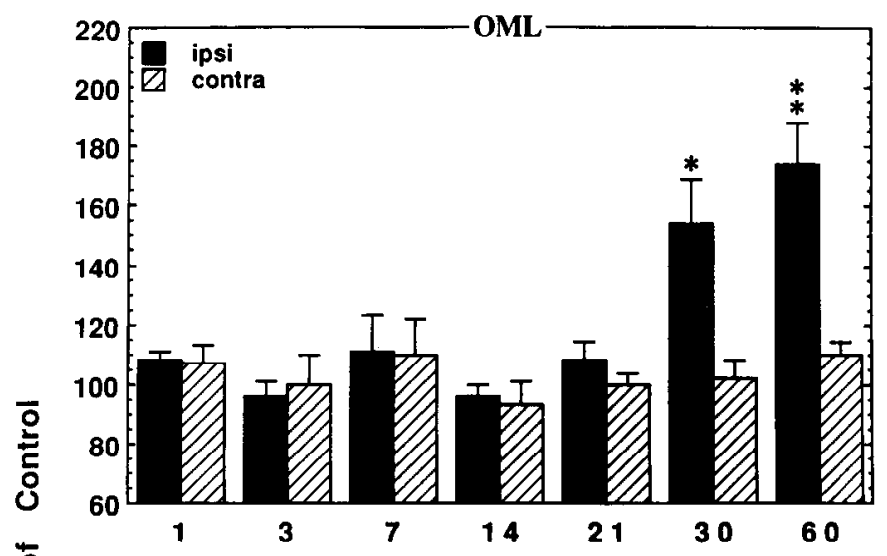

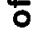

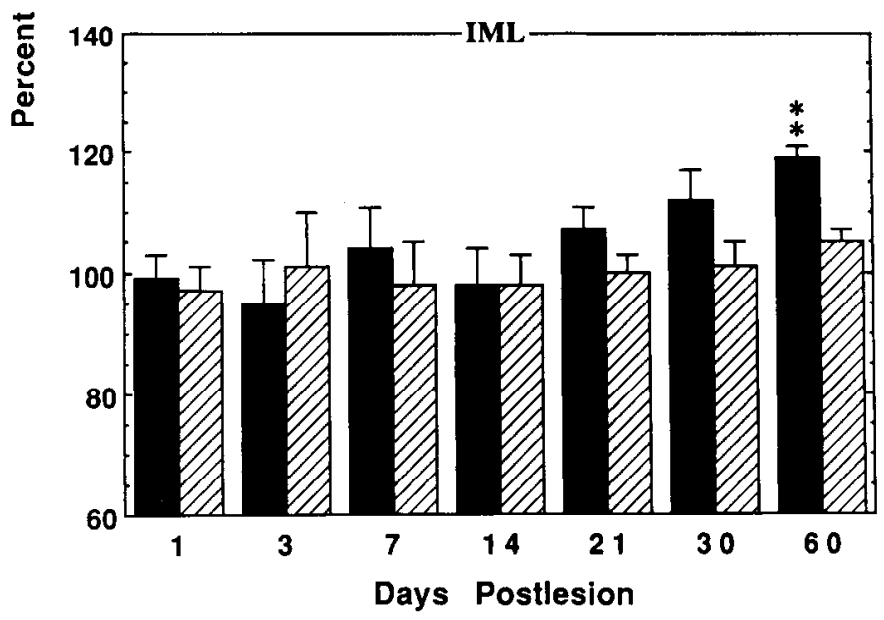

Figure 2. $\left[{ }^{3} \mathrm{H}\right] \mathrm{KA}$ binding in the ventral blade of the ipsilateral and contralateral dentate gyrus at different postlesion times. The groups are the same as in Figure $1 .{ }^{*} p<0.05 ;{ }^{* *} p<0.001$ (Student's $t$-test, 2-tailed).

trols (data not shown). At this time, the density was highest in the inner one-third of the ML of the dorsal and ventral blade.

The first changes in the distribution profiles were observed at $21 \mathrm{~d}$ postlesion when the layer enriched in $\mathrm{KA}$ receptor binding becomes $15-42 \%$ wider than that of the unoperated control and the contralateral hippocampus (Table 1). Thirty to sixty days postlesion the layer enriched in KA binding sites becomes even wider (40-80\%), an indication of the expansion of the KA receptor-rich zone from the inner one-third into the denervated outer two-thirds of the ML (compare Figs. 6 and 7 with the data in Table 1). Similar effects of lesions were observed in each of the 3 portions of the ML sampled. However, the increase in the width of the layer with high level of binding appeared larger in the ventral blade (Fig. 6c, Tablc 1). No changes in the distribution of receptor binding were seen in the contralateral dentate gyrus at any time point (Table 1 ).

\section{Saturation analysis of $\left[{ }^{3} \mathrm{H}\right] \mathrm{KA}$ binding in the dentate gyrus} molecular layer

The density and affinity of $\left[{ }^{3} \mathrm{H}\right] \mathrm{KA}$ binding were studied by performing saturation binding analysis in the presence or absence of $10 \mathrm{~mm} \mathrm{Ca}$-acetate. Binding in the presence of $\mathrm{Ca}^{2+}$ was investigated since previous studies (Honoré et al., 1986; Monaghan et al., 1986) indicate that $\mathrm{Ca}^{2+}$ selectively inhibits $\left[{ }^{3} \mathrm{H}\right] \mathrm{KA}$ binding to the high affinity KA binding sites but not to the low 


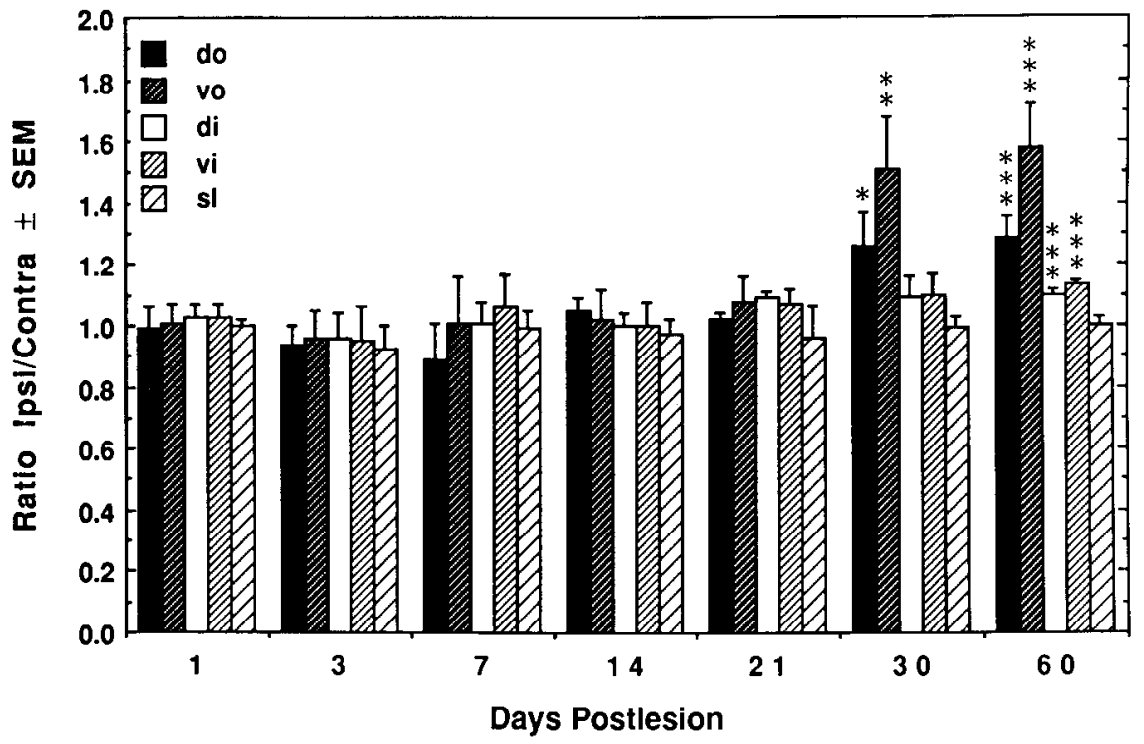

Figure 3. Ratio of $\left[{ }^{3} \mathrm{H}\right] \mathrm{KA}$ binding levels in different areas of the ipsilateral and contralateral hippocampus. The areas shown: outer two-thirds, inner one-third of the dentate gyrus ML dorsal $(d o, d i)$ and ventral blade $(v o, v i)$, and stratum lucidum $(s l) .{ }^{*} p<0.05$; ${ }^{* *} p<0.01 ;{ }^{* * *} p<0.001$ ipsilateral vs contralateral (1-way ANOVA, Scheffe $F$-test). affinity sites. Therefore, this strategy provides an alternate means of differentiating the high and low affinity KA binding sites.

\section{Saturation binding in unoperated controls}

Because of the limited resolution of the autoradiograms representing binding at the lowest concentrations (0.9-2.0 nM) of radioligand used (binding was in the range of background) only the 8 highest radioligand concentrations from the initial 10 concentrations were used for evaluation of kinetic parameters of the binding in the absence of $\mathrm{Ca}^{2+}$ and 7 concentrations for binding in the presence of $\mathrm{Ca}^{2+}$.

In the ML of unoperated controls, binding with $\left[{ }^{3} \mathrm{H}\right] \mathrm{KA}$ at a concentration of $50 \mathrm{nM}$ revealed a $25 \%$ decrease in the binding level in the presence of $\mathrm{Ca}^{2+}$. The percentage of inhibition was uniform across the ML. Binding in the stratum lucidum was inhibited by about $34 \%$. At the highest concentration of $\left[{ }^{3} \mathrm{H}\right] \mathrm{KA}$ used ( $400 \mathrm{nM}$ ), the inhibition of binding was about $22 \%$ for the outer $2 / 3$ of the ML, $17 \%$ for the inner $1 / 2$ of the ML, and $16 \%$ for stratum lucidum. This indicates that high affinity $\mathrm{KA}$ binding sites constitute a relatively small population of $\mathrm{K} \Lambda$ receptors in the ML.

In the absence of $\mathrm{Ca}^{2+}$, the specific binding of $\left[{ }^{3} \mathrm{H}\right] \mathrm{KA}$ in sections taken from unoperated controls saturated with increasing concentrations of radioligand (2-400 nM). The Scatchard plot was occasionally slightly curvilinear, suggesting the presence of 2 different populations of binding sites with high and low affinity for $\left[{ }^{3} \mathrm{H}\right] \mathrm{KA}$. In spite of this, the nonlinear computer

Table 1. Time course of changes in the distribution of KA binding sites in the molecular layer of the dorsal and ventral blades of the dentate gyrus

\begin{tabular}{|c|c|c|c|c|c|c|}
\hline \multirow[b]{3}{*}{ Day } & \multicolumn{6}{|c|}{ Hippocampal arca } \\
\hline & \multicolumn{2}{|l|}{$\mathrm{a}$} & \multicolumn{2}{|l|}{$\mathrm{b}$} & \multicolumn{2}{|l|}{ c } \\
\hline & Ipsi & Contra & Ipsi & Contra & Ipsi & Contra \\
\hline \multirow[t]{2}{*}{1} & $70.08 \pm 9.28$ & $71.30 \pm 10.07$ & $59.02 \pm 5.64$ & $57.80 \pm 5.37$ & $68.86 \pm 3.26$ & $71.30 \pm 6.52$ \\
\hline & $101 \%$ & $102 \%$ & $99 \%$ & $97 \%$ & $92 \%$ & $95 \%$ \\
\hline \multirow[t]{2}{*}{3} & $70.08 \pm 3.83$ & $71.30 \pm 5.02$ & $66.39 \pm 1.06$ & $64.55 \pm 4.51$ & $78.68 \pm 10.92$ & $76.24 \pm 10.71$ \\
\hline & $108 \%$ & $109 \%$ & $114 \%$ & $111 \%$ & $109 \%$ & $106 \%$ \\
\hline \multirow[t]{2}{*}{7} & $75.61 \pm 3.91$ & $68.24 \pm 1.31$ & $64.55 \pm 9.13$ & $64.55 \pm 9.13$ & $84.84 \pm 0.03$ & $81.15 \pm 0.10$ \\
\hline & $107 \%$ & $100 \%$ & $103 \%$ & $103 \%$ & $98 \%$ & $94 \%$ \\
\hline \multirow[t]{2}{*}{14} & $71.93 \pm 5.32$ & $67.61 \pm 6.15$ & $60.86 \pm 1.51$ & $56.25 \pm 5.26$ & $71.30 \pm 8.60$ & $63.92 \pm 5.37$ \\
\hline & $105 \%$ & $99 \%$ & $109 \%$ & $101 \%$ & $97 \%$ & $87 \%$ \\
\hline \multirow[t]{2}{*}{21} & $82.99 \pm 2.81$ & $65.18 \pm 0.62$ & $76.83 \pm 4.30$ & $64.55 \pm 1.06$ & $103.91 \pm 11.39$ & $71.30 \pm 6.84$ \\
\hline & $115 \% *$ & $90 \%$ & $124 \% *$ & $104 \%$ & $142 \% *$ & $98 \%$ \\
\hline \multirow[t]{2}{*}{30} & $101.43 \pm 8.03$ & $62.08 \pm 6.92$ & $99.59 \pm 4.26$ & $68.86 \pm 2.45$ & $93.43 \pm 7.48$ & $59.64 \pm 4.02$ \\
\hline & $159 \% * *$ & $98 \%$ & $146 \% * *$ & $101 \%$ & $157 \% * *$ & $100 \%$ \\
\hline \multirow[t]{2}{*}{60} & $105.75 \pm 13.52$ & $70.08 \pm 9.28$ & $103.28 \pm 9.03$ & $71.00 \pm 5.25$ & $140.16 \pm 14.76$ & $82.07 \pm 3.77$ \\
\hline & $153 \% * *$ & $101 \%$ & $139 \% * *$ & $95 \%$ & $178 \% * * *$ & $104 \%$ \\
\hline
\end{tabular}

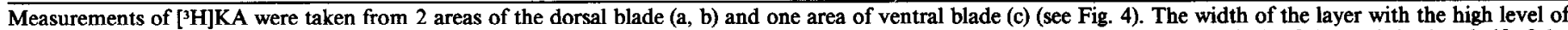

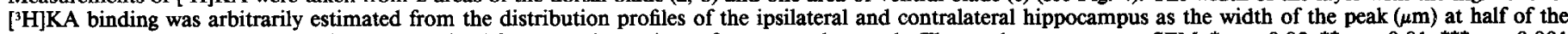

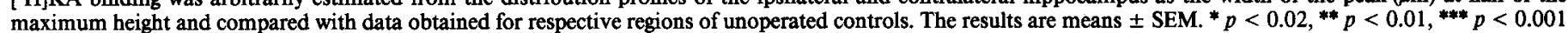
vs. control (Student's $t$-test). 


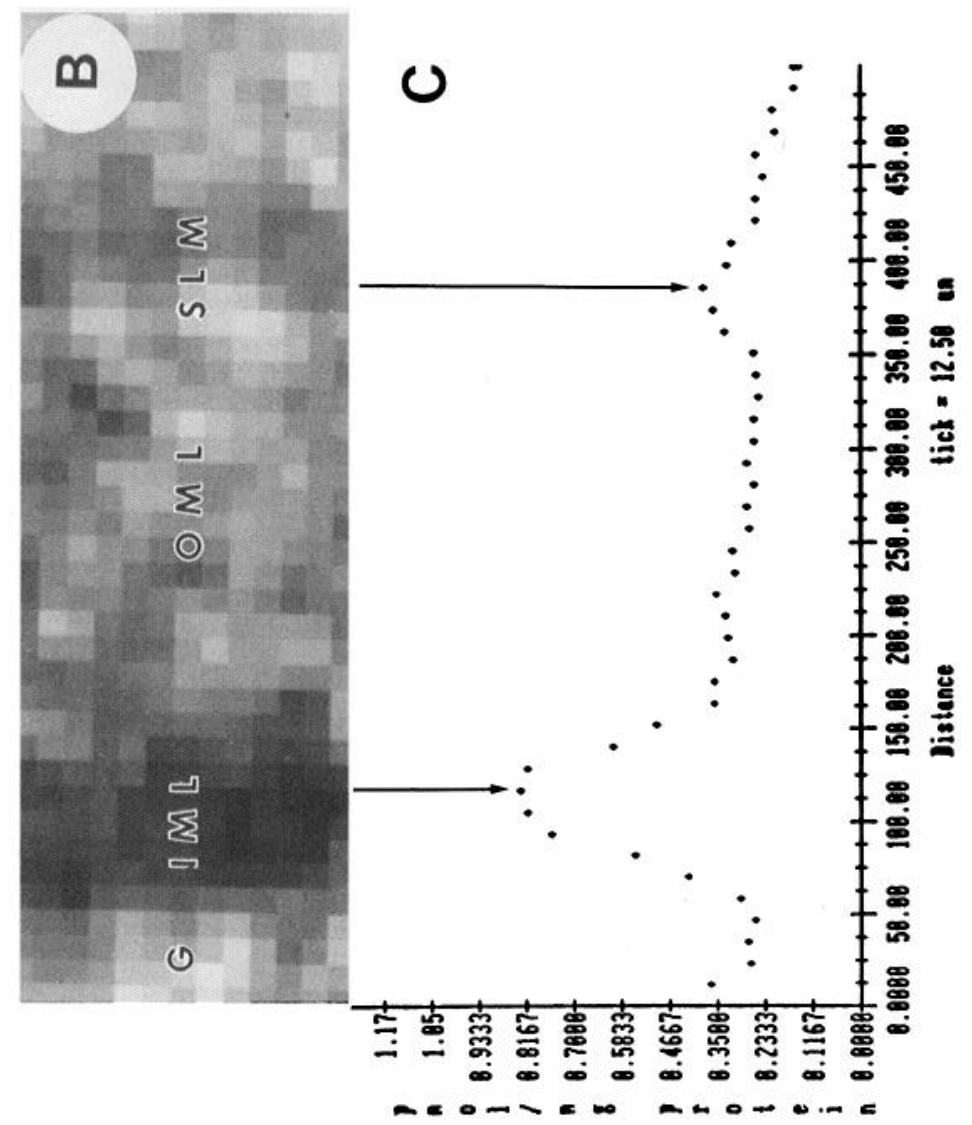

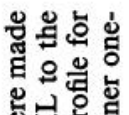

幽完

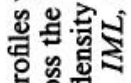

究象

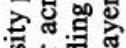

过完

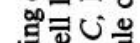

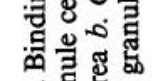

क्ष

密

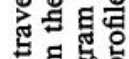

등 해음

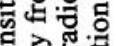

중

ํㅡㄹ 을

궁

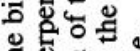

염.

웡응

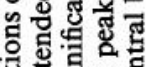

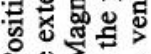
․

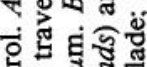

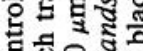
융요요

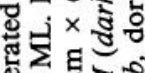

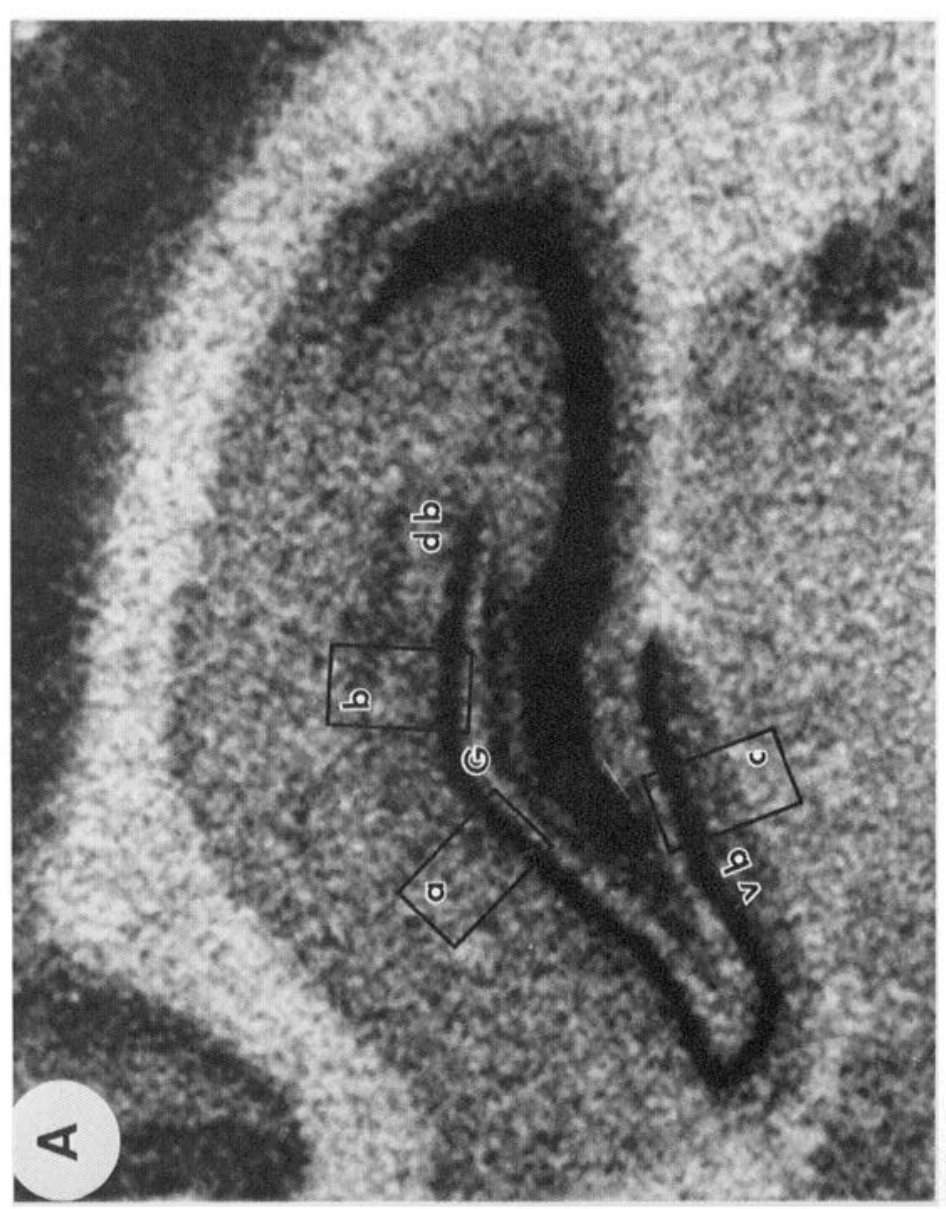

员

르에 웡물 势焉。 家可 论 응 荷.

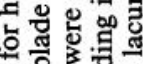
틀 형멸 颚结旸 영 년 ส. ฮึ:

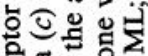
ه্웡 远高 可.

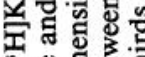

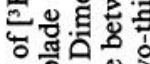
证

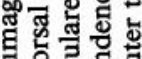
웡 赵要造 ․․ 응 8 o × ॐ

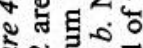
놇욜 

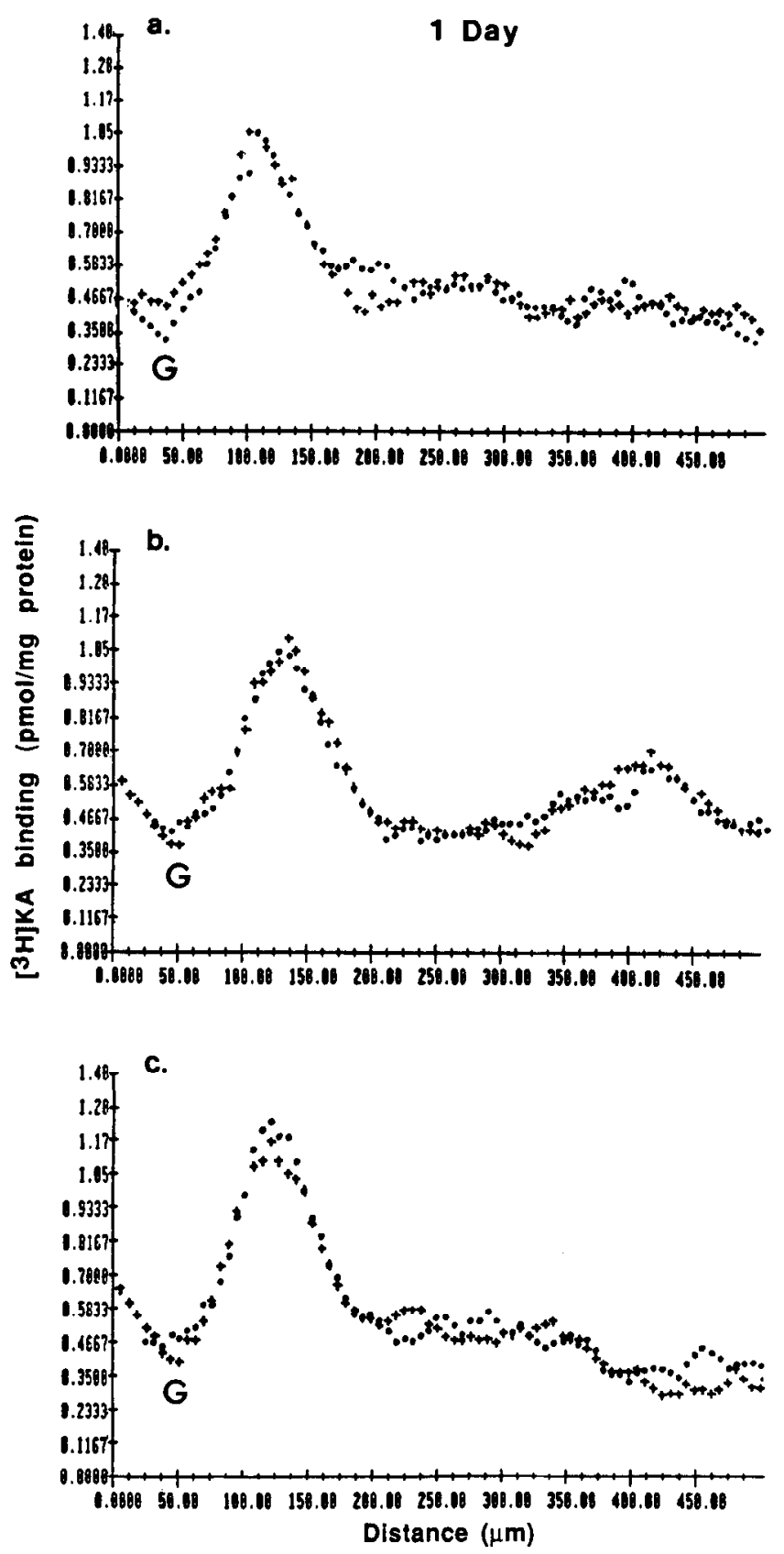

Figure 5. Representative computer-generated $\left[{ }^{3} \mathrm{H}\right] \mathrm{KA}$ binding density profiles in 3 different areas of the dentate gyrus ML of the ipsilateral and contralateral hippocampus $1 \mathrm{~d}$ after unilateral entorhinal cortex lesions. The positions of the scanned areas are as those marked in Figure $4 A$ as $a, b$, and $c$. Binding density profiles for the ipsilateral hippocampus $(+)$ were superimposed on profiles obtained for the same region of the contralateral hippocampus (O). Note the very similar pattern of distribution and density of receptors in the ipsilateral and contralateral hippocampus. $G$ marks the position of the granule cell layer.

analysis of binding did not consistently fit a 2-site model, probably owing to the difficulty in obtaining useful quantitative autoradiographic ligand binding values at very low ligand concentrations. Therefore, a singlc-sitc modcl has been chosen for analysis of the data. Using this model, the apparent dissociation constant $\left(K_{d}\right)$ for KA receptors in the dentate gyrus ML was 8$15 \mathrm{~nm}$ (Table 2), which agrees with the $K_{\mathrm{d}}$ for KA receptors measured in human brain hippocampus (Cowburn et al., 1989).
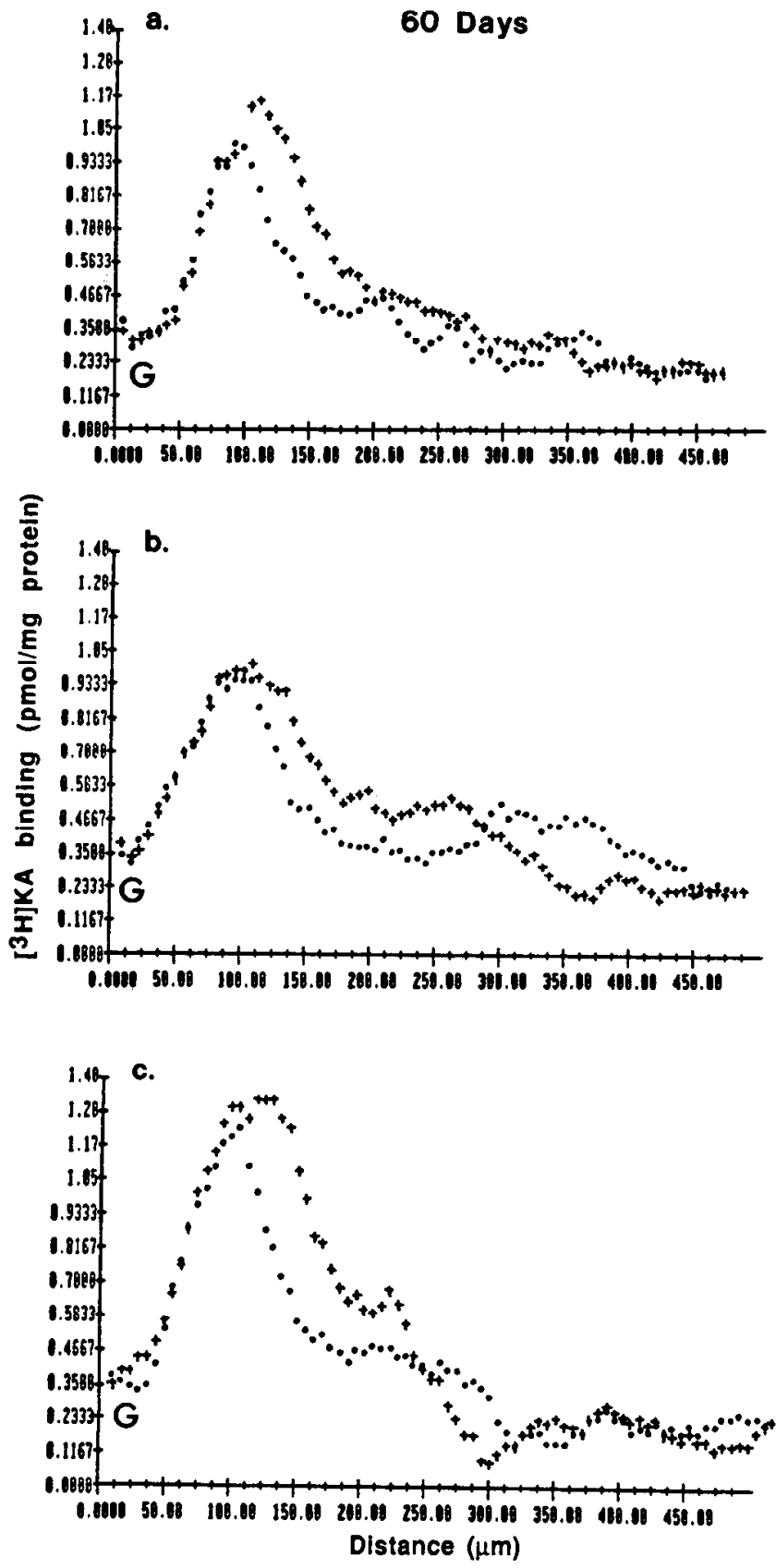

Figure 6. Representative $\left[{ }^{3} \mathrm{H}\right] \mathrm{KA}$ binding density profiles in 3 different arcas of the dentate gyrus $\mathrm{ML}$ of the ipsilateral $(+)$ and contralateral (๑) hippocampus $60 \mathrm{~d}$ after unilateral entorhinal cortex lesions. Note the expansion of the KA binding zone in the ipsilateral hippocampus. Other explanations as in Figure 5. Compare data in Table 1.

The maximal binding site density $\left(B_{\max }\right)$ was $0.299 \mathrm{pmol} / \mathrm{mg}$ protein for the outer two-thirds of the ML of the dorsal blade and $0.883 \mathrm{pmol} / \mathrm{mg}$ protein for the inner one-third of the ML of the dorsal blade, and 0.450 and $0.995 \mathrm{pmol} / \mathrm{mg}$ protein for the outer two-thirds and inner one-third of the ML of the ventral blade, respectively (Table 2 ).

In the presence of $\mathrm{Ca}^{2+}$, the Scatchard plot became linear, indicating that under these conditions $\left[{ }^{3} \mathrm{H}\right] \mathrm{KA}$ binds to a single homogeneous population of receptor sites with a $K_{\mathrm{d}}$ of about 20-30 nM and $B_{\max }$ of $0.237 \mathrm{pmol} / \mathrm{mg}$ protein for the outer twothirds of the ML of the dorsal blade, $0.826 \mathrm{pmol} / \mathrm{mg}$ protein 


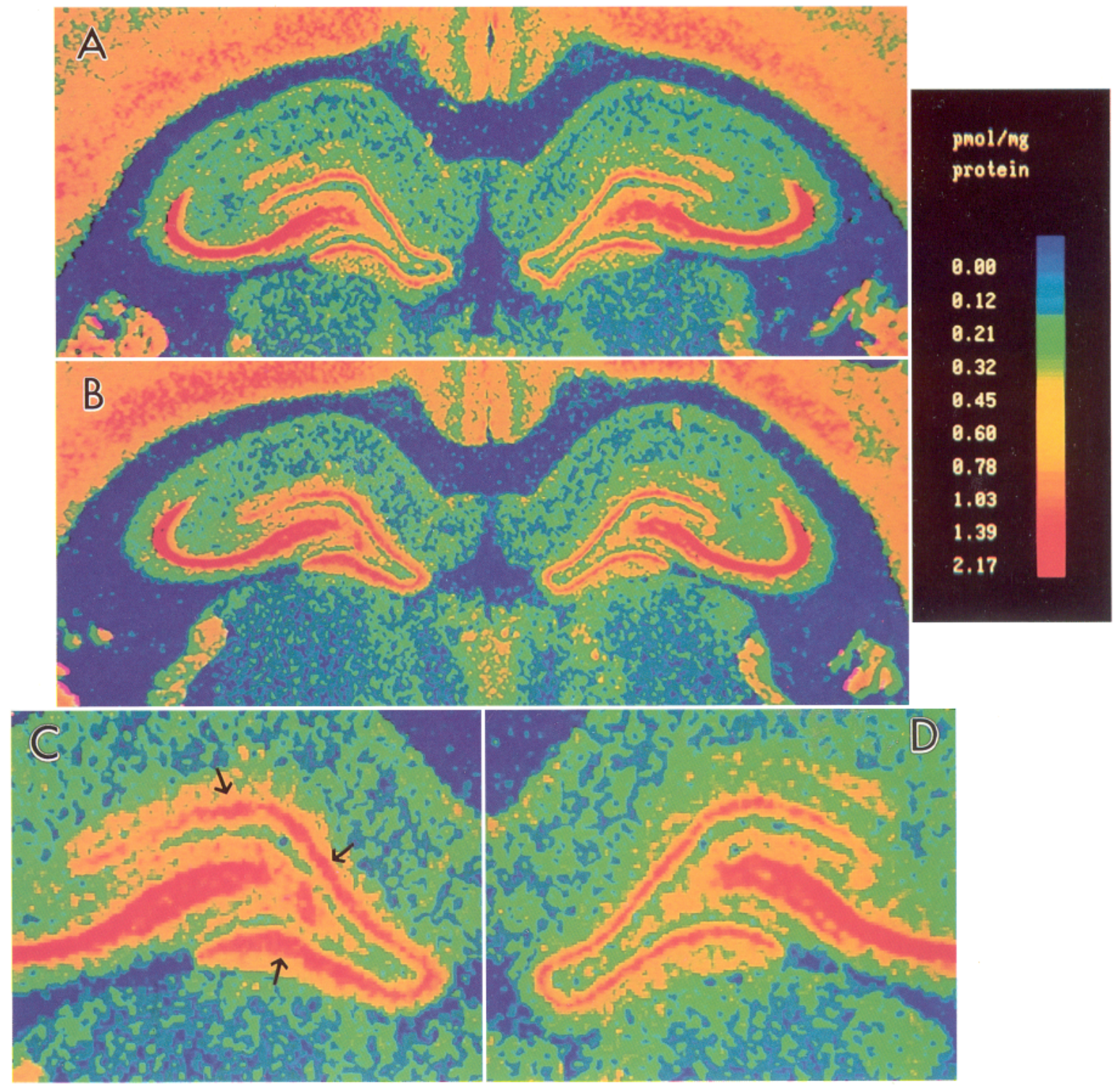

Figure 7. Computerized image of $\left[{ }^{3} \mathrm{H}\right] \mathrm{KA}$-binding site autoradiograms for: $(A)$ the hippocampi of a control animal and $(B)$ ipsilateral $(l e f t)$ and contralateral (right) hippocampus of an operated rat $60 \mathrm{~d}$ after unilateral entorhinal cortex lesions. Digital images of binding are color-coded with low-to-high densities represented on the spectral bar from blue to red. KA receptors were labeled with $50 \mathrm{~nm}\left[{ }^{3} \mathrm{H}\right] \mathrm{KA}$. $C$ and $D$, Magnification $(2 \times)$ of the ipsilateral and contralateral dentate gyrus regions, respectively, shown in $B$. Note the substantial increase in the width of the zone occupied by KA receptors (arrows) in the ML of the ipsilateral hippocampus in comparison to the width of those in the contralateral and control hippocampi.

Table 2. Kinetic constants for the binding of $\left[{ }^{3} \mathrm{H}\right] \mathrm{KA}$ to the molecular layer of the ipsilateral and contralateral hippocampus $60 \mathrm{~d}$ after unilateral entorhinal cortex lesions

\begin{tabular}{|c|c|c|c|c|c|c|c|c|}
\hline & \multicolumn{2}{|l|}{ Dorsal-OML } & \multicolumn{2}{|c|}{ Dorsal-IML } & \multicolumn{2}{|c|}{ Ventral-OML } & \multicolumn{2}{|c|}{ Ventral-IML } \\
\hline & $\overline{K_{\mathrm{d}}}$ & $B_{\max }$ & $K_{\mathrm{d}}$ & $B_{\max }$ & $K_{\mathrm{d}}$ & $B_{\max }$ & $K_{\mathrm{d}}$ & $B_{\max }$ \\
\hline Control & $9.63 \pm 0.44$ & $0.299 \pm 0.018$ & $8.21 \pm 0.13$ & $0.883 \pm 0.020$ & $12.96 \pm 0.43$ & $0.450 \pm 0.032$ & $7.62 \pm 0.33$ & $0.995 \pm 0.026$ \\
\hline $\begin{array}{l}\text { Ipsilateral } \\
\text { (\% control) }\end{array}$ & $9.63 \pm 0.53$ & $\begin{array}{l}0.437 \pm 0.008 \\
146 \% * *\end{array}$ & $8.07 \pm 0.12$ & $\begin{array}{l}0.963 \pm 0.013 \\
109 \%\end{array}$ & $14.89 \pm 1.16$ & $\begin{array}{l}0.895 \pm 0.040 \\
199 \% * *\end{array}$ & $9.29 \pm 0.52$ & $\begin{array}{l}1.103 \pm 0.027 \\
111 \% *\end{array}$ \\
\hline $\begin{array}{l}\text { Contra- } \\
\text { lateral }\end{array}$ & $10.37 \pm 0.71$ & $0.320 \pm 0.031$ & $8.92 \pm 0.41$ & $0.936 \pm 0.013$ & $13.28 \pm 0.82$ & $0.475 \pm 0.031$ & $9.23 \pm 0.69$ & $0.984 \pm 0.022$ \\
\hline
\end{tabular}

Eight different radioligand concentrations $(2-400 \mathrm{nM})$ were used and computer analysis of binding data was performed. $K_{\mathrm{d}}$, the apparent dissociation constant (nM), and $B_{\max }$, maximal number of binding sites (pmol/mg protein); dorsal-OML, dorsal-IML, outer two-thirds and inner third of the dorsal blade molecular layer; ventralOML, ventral-IML, outer two-thirds and inner-third of the ventral blade molecular layer. Values are given as means $\pm \mathrm{SEM}^{*}{ }^{*} p<0.05 ;{ }^{* *} p<0.001$ vs. control (Student's $t$-test, 2-tailed). 

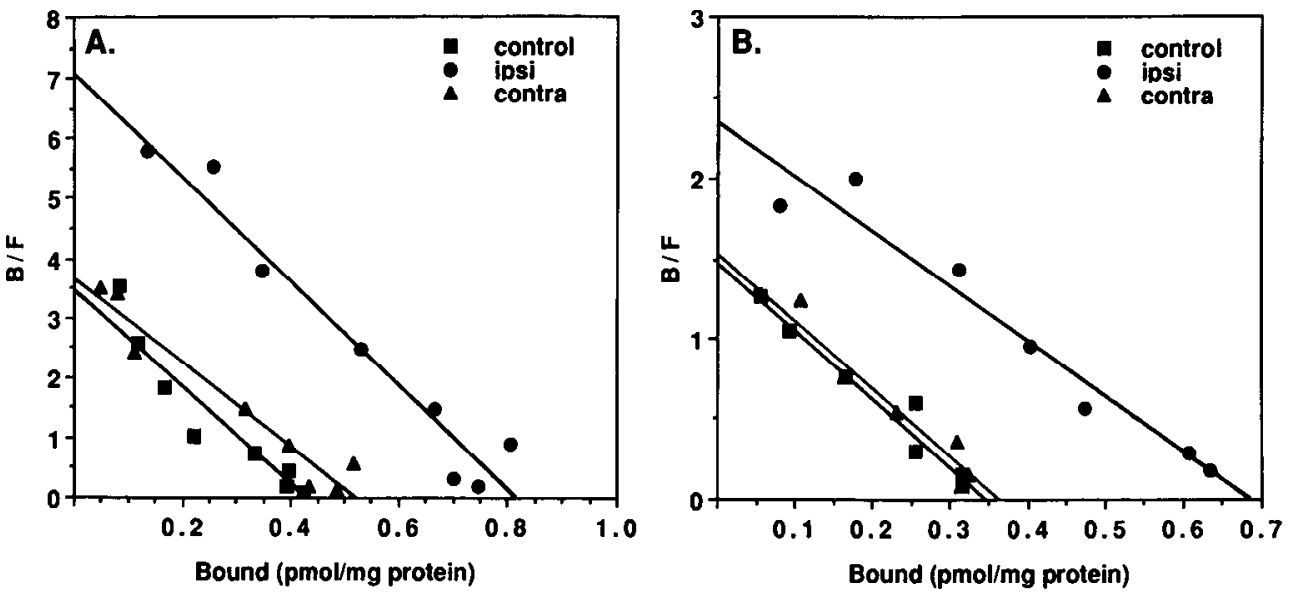

Figure 8. Representative plots of the Scatchard transformed $\left[{ }^{3} \mathrm{H}\right] \mathrm{KA}$ binding data for the outer two-thirds of the ventral blade ML in the control, ipsilateral and contralateral hippocampus $60 \mathrm{~d}$ after unilateral entorhinal cortex lesions. $A$, Binding in the absence of Ca-acetate; $B$, binding in the presence of $10 \mathrm{~mm}$ $\mathrm{Ca}$-acetate. The lines represent the best fit using the single-site model. Other explanations as in Tables 2 and 3. for the inner one-third of the ML of the dorsal blade, and 0.378 $\mathrm{pmol} / \mathrm{mg}$ protein and $0.942 \mathrm{pmol} / \mathrm{mg}$ protein for the outer twothirds and inner one-third of the ML of the ventral blade, respectively (Table 3 ). The $K_{\mathrm{d}}$ value for low affinity KA binding sites was similar to that shown by Monaghan and co-workers (1986) for $\left.{ }^{3} \mathrm{H}\right] \mathrm{KA}$ binding to rat brain synaptic plasma membranes.

\section{Saturation binding in lesioned animals}

Sixty days after entorhinal lesions, evaluation of binding parameters for the ipsilateral and contralateral hippocampus in the absence of $\mathrm{Ca}^{2+}$ showed no significant changes in $K_{\mathrm{d}}$ for the mixed population of the high and low affinity KA binding sites. The observed changes in the binding in the ipsilateral ML corresponded to a change in receptor density (Table 2, Fig. 8A). The $B_{\max }$ values for the ipsilateral outer two-thirds of the ML of the dorsal and ventral blade significantly increased, reaching $146 \%(p<0.001)$ and $199 \%(p<0.001)$ of unoperated controls, respectively. A small increase in the density of KA receptors was also found in the inner one-third of the ML of the ventral blade (111\% of control, $p<0.05$ ). No changes in $B_{\max }$ were observed in any of the areas examined in the contralateral hippocampus (Table 2).

Binding in the presence of $\mathrm{Ca}^{2+}$ (Table 3, Fig. 8B) also revealed an increase in $B_{\max }$ of low affinity $\mathrm{KA}$ binding sites in the outer two-thirds of the ML of the ipsilateral hippocampus.
Elevated density of low affinity binding sites was detected in the outer two-thirds of the ML of both the dorsal (159\% of control, $p<0.001)$ and ventral blade $(204 \%, p<0.001)$. This increase in $\mathrm{KA}$ binding sites observed in saturation binding analysis at $60 \mathrm{~d}$ postlesion was comparable to the increase observed in single-concentration (50 nM $\left[{ }^{3} \mathrm{H}\right] \mathrm{KA}$ ) binding assays (compare data in Table 3 with data in Figs. 1 and 2). No significant changes in the density of low affinity binding sites were observed in the inner $1 / 3$ of the ML of the dorsal and ventral blade of either the ipsilateral or contralateral dentate gyrus or in the outer twothirds of the ML of the contralateral hippocampus as compared to unoperated controls (Table 3).

To determine if high affinity $\mathrm{KA}$ sites are also altered at 60 $\mathrm{d}$ postlesion, the amount of binding that is reduced by the presence of $\mathrm{Ca}^{2+}$ was calculated in the ML of the ipsilateral and control hippocampus (Fig. 9). Similar to the low affinity binding sites $\left(\mathrm{Ca}^{2+}\right.$-insensitive), whose density was significantly elevated in the outer two-thirds of the ML (150\% of control in the dorsal blade and $182 \%$ of control in the ventral blade, $p<0.01$ ), binding to the high affinity sites also increased significantly and reached $216 \%$ of control in the dorsal blade $(p<0.05)$ and $263 \%$ of control in the ventral blade $(p<0.05)$. Elevated levels of binding to the high affinity component were also observed in the inner one-third of the ipsilateral ML (156\% of control in the dorsal blade and $150 \%$ of control in the ventral blade), although these values did not reach statistical significance. The
A

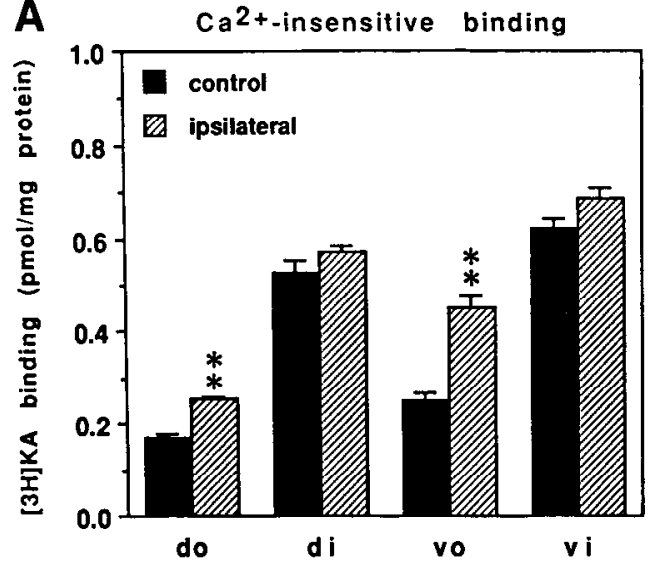

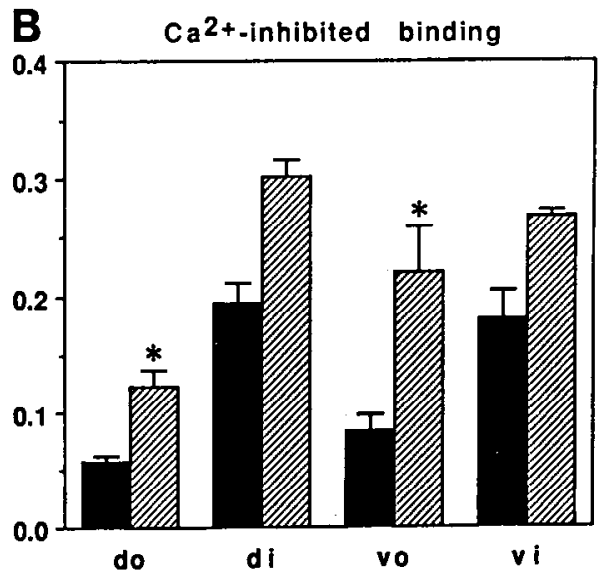

Figure 9. Low and high affinity component of $\left[{ }^{3} \mathrm{H}\right] \mathrm{KA}$ binding in the ML of unoperated control and ipsilateral hippocampus $60 \mathrm{~d}$ after unilateral entorhinal cortex lesions. $A$, Density of binding sites (50 $\left.\mathrm{nm}\left[{ }^{3} \mathrm{H}\right] \mathrm{KA}\right)$ assessed in the presence of $10 \mathrm{~mm}$ Ca-acetate $\left(\mathrm{Ca}^{2+}\right.$-insensitive, low affinity binding sites). $B$, Binding to $\mathrm{Ca}^{2+}$-sensitive (high affinity) binding sites, i.e., binding inhibited by the presence of $10 \mathrm{~mm}$ Caacetate (total binding minus binding in the presence of calcium). do, di, Outer two-thirds and inner one-third of the dorsal blade ML; vo, vi, outer two-thirds and inner one-third of the ventral blade ML. Values are means \pm SEM from 4 rats. Significantly different from control: ${ }^{*} p<0.05 ;{ }^{* *} p<0.01$ (1-way ANOVA, Scheffe $F$-test). 
Table 3. Kinetic constants for the binding of $\left[{ }^{3} \mathrm{H}\right] \mathrm{KA}$ in the presence of $10 \mathrm{mM}$ Ca-acetate to the molecular layer of the ipsilateral and contralateral hippocampus $60 \mathrm{~d}$ after unilateral entorhinal cortex lesions

\begin{tabular}{|c|c|c|c|c|}
\hline & \multicolumn{2}{|l|}{ Dorsal-OML } & \multicolumn{2}{|l|}{ Dorsal-IML } \\
\hline & $\overline{K_{d}}$ & $B_{\max }$ & $\overline{K_{\mathrm{d}}}$ & $B_{\max }$ \\
\hline Control & $18.48 \pm 0.90$ & $0.237 \pm 12.3$ & $28.67 \pm 3.01$ & $0.826 \pm 0.046$ \\
\hline $\begin{array}{l}\text { Ipsilateral } \\
\text { (\% control) }\end{array}$ & $23.12 \pm 1.70$ & $\begin{array}{l}0.377+0.012 \\
159 \% *\end{array}$ & $28.47 \pm 1.16$ & $\begin{array}{l}0.886 \pm 0.028 \\
107 \%\end{array}$ \\
\hline $\begin{array}{l}\text { Contralateral } \\
\text { ( } \% \text { control) }\end{array}$ & $21.20 \pm 2.91$ & $\begin{array}{l}0.252 \pm 0.028 \\
106 \%\end{array}$ & $29.78 \pm 1.58$ & $\begin{array}{l}0.834 \pm 0.022 \\
101 \%\end{array}$ \\
\hline
\end{tabular}

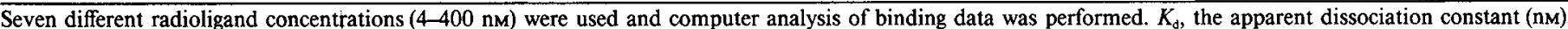

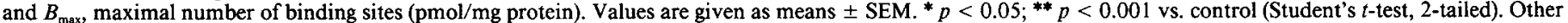
explanations as in legend of Table 2.

data suggest that the increase in the binding levels at later postlesion times probably reflects the increase in the density of low as well as high affinity binding sites.

\section{Discussion}

The present paper analyzes the response of hippocampal kainate receptors to deafferentation and subsequent reinnervation of the dentate gyrus ML following unilateral lesions of the entorhinal cortex. The data suggest that the observed dynamics of changes in the density of $\left[{ }^{3} \mathrm{H}\right] \mathrm{KA}$ binding sites may relate to postlesion changes in the innervation pattern of the denervated ML.

The specific neuronal cell types in the dentate gyrus on which $\mathrm{KA}$ receptors are localized have not yet been identified. The lack of early changes in KA binding sites in the outer two-thirds of the ML after entorhinal ablation suggests (1) that KA receptors are not presynaptically localized on entorhinal fiber terminals, and (2) that they may be postsynaptically located. This hypothesis is consistent with the observation that destruction of the dentate gyrus granule cells by colchicine eliminates the band of KA binding sites in the dentate gyrus ML (Monaghan and Cotman, 1982). The observation that KA sites in the outer two-thirds of the ML do not decrease in density following entorhinal lesions also suggests that these receptors are not located postsynaptically in the entorhinal terminal synapse. Soon after entorhinal cortical ablation, there is a loss of the postsynaptic density structure (Hoff et al., 1982a), and this appears to be associated with a loss of receptors within the postsynaptic density (e.g., cholinergic muscarinic, NMDA and quisqualate receptors) (Monaghan et al., 1982; Uhas et al., 1990).

It is possible that KA binding sites of the inner one-third of the ML are localized postsynaptically since they are only lost when granule cells are removed and not when the cells in the CA4 hilus are removed (Monaghan and Cotman, 1982). However, the precise localization of KA receptors will require further experiments with different methods such as immunohistochemistry. Although it is also possible that some of the changes in KA binding may be due to KA receptor sites located on glial cells (Backus et al., 1989), this possibility seems unlikely since: (1) it has not been possible to show $\left[{ }^{3} \mathrm{H}\right] \mathrm{KA}$ binding sites on glial cells (Bridges et al., 1987), (2) the distribution of KA binding sites in the dentate gyrus ML does not correspond to the distribution of glial cells (Rose et al., 1976; Gage et al., 1988), and (3) the time course and pattern of changes in KA binding sites, observed in the present study, do not correlate to the time course and pattern of glial responses following removal of the entorhinal projections to the ML (Rose et al., 1976; Vijayan and Cotman, 1983; Gage et al., 1988).
Independent of their cellular localization, KA sites of the inner one-third of the ML are spatially associated with this discrete synaptic zone. Following the reorganization and expansion of this zone, KA binding sites respond to maintain their association with it. Specifically, after damage to the entorhinal cortex, the fibers of the C/A pathway expand their terminal field from the inner one-third into the denervated outer two-thirds of the ML, invading territory normally innervated by entorhinal projections (Zimmer, 1973; Lynch et al., 1975). The commissural and associational systems spread out to almost the same degree, i.e., to about $140 \%$ of the normal width (Lynch et al., 1973, 1976). The degree of expansion of $\mathrm{C} / \mathrm{A}$ fibers correlates with the degree of expansion of the layer enriched in KA binding sites from the inner one-third into the outer two-thirds of the dentate gyrus ML 30-60 d postlesion (see Table 1). The similarity in the response of the reinnervating fibers and KA receptors speaks in favor of the hypothesis that changes in the distribution of KA receptors after entorhinal lesions reflect mostly anatomical reorganization of the denervated dentate gyrus. Comparison between the time course of the expansion of $\mathrm{C} / \mathrm{A}$ afferents (Lynch et al., 1977) and the increase in the $\left[{ }^{3} \mathrm{H}\right] \mathrm{KA}$ binding levels indicates that redistribution of $\mathrm{C} / \mathrm{A}$ afferents precedes the changes in receptors by about 2-3 weeks. The increase in $\mathrm{KA}$ receptor binding correlates with the time course of the postlesion changes in the density of presynaptic terminals and synaptic densities (Steward and Vinsant, 1983), suggesting that the formation of new synapses in the denervated zone, and perhaps their subsequent stabilization, may be necessary for the expression of KA receptors.

Dynamic changes in the distribution profile of KA receptors were confirmed by direct measurement of $\left[{ }^{3} \mathrm{H}\right] \mathrm{KA}$ binding levels in the inner one-third and outer two-thirds of the ML. These measurements revealed, at 30-60 d postlesion, a statistically significant elevation (30-70\%) in the binding levels in the outer two-thirds of the ML, in both the dorsal and ventral blade of the ipsilateral dentate gyrus. No such changes were observed in the contralateral hippocampus. Since the ipsilateral dentate gyrus ML shrinks on average about 15-20\% (Lynch et al., 1976) after entorhinal lesions, especially at later postoperative times, our values might be somewhat overestimated. However, because our measurements were taken from the entire outer twothirds of the ML, whereas C/A fibers sprout into the denervated zone after entorhinal lesions and occupy only the inner one-half of the outer two-thirds of the ML, the changes in the binding levels we observed are probably underestimated.

Sixty days postlesion a small (16-19\%) but significant increase in the KA binding level was found in the directly non- 
Table 3. Continued

\begin{tabular}{llll} 
Ventral-OML & & Ventral-IML & \\
\cline { 2 - 4 }$K_{\mathrm{d}}$ & $B_{\max }$ & $K_{\mathrm{d}}$ & $B_{\max }$ \\
\hline $28.28 \pm 2.85$ & $0.378 \pm 0.034$ & $25.80 \pm 2.62$ & $0.924 \pm 0.043$ \\
$34.95 \pm 2.55$ & $0.772 \pm 0.043$ & $29.97 \pm 0.83$ & $1.029 \pm 0.040$ \\
& $204 \%^{*}$ & & $111 \%$ \\
$25.50 \pm 2.28$ & $0.365 \pm 0.044$ & $27.05 \pm 1.94$ & $0.865 \pm 0.032$ \\
& $97 \%$ & & $94 \%$ \\
\end{tabular}

denervated inner one-third of the ML (Fig. 2). This effect may be a reflection of the expansion of this layer. As seen in Figure 6 , a careful laminar-density analysis indicates that the zone rich in KA sites appears as a broader peak $60 \mathrm{~d}$ postlesion. Thus, values taken from the outer portions of the inner one-third of the ML would be higher because of the widening of the peak.

The observed increases in the $\left[{ }^{3} \mathrm{H}\right] \mathrm{KA}$ binding levels do not represent an increase in KA receptor affinity, but rather reflect changes in the actual density of receptors. The results from saturation binding analysis indicate a change in $B_{\max }$ but not in $K_{\mathrm{d}}$. KA binding in the absence of calcium-acetate, however, represents binding to a mixed population of high and low affinity KA sites which were not possible to resolve (because of the difficulty in obtaining accurate density measurements at low ligand concentrations with this technique).

To further identify the specific KA receptor changes, KA binding affinity and density were also determined in the presence of calcium-acetate. Binding in the presence of $\mathrm{Ca}^{2+}$ revealed only one population of KA receptor sites with a $K_{\mathrm{d}}$ of 20-30 nM. This $K_{\mathrm{d}}$ was about 2-3 times higher than the $K_{\mathrm{d}}$ of 8-15 nM for the mixed population of binding sites detectable in the absence of $\mathrm{Ca}^{2+}$. This result agrees with previous reports (Honoré et al., 1986; Monaghan et al., 1986) which showed that $\mathrm{Ca}^{2+}$ selectively inhibits $\left[{ }^{3} \mathrm{H}\right] \mathrm{KA}$ binding to the high affinity receptor sites. The $K_{\mathrm{d}}$ value for low affinity KA binding sites was similar to that estimated for low affinity binding sites in membrane preparation from rat brain (Monaghan et al., 1986). The analysis of $\mathrm{KA}$ binding data indicates that there is an increase in the number of low affinity KA binding sites, but no change in their affinity, in the outer two-thirds of the ipsilateral ML at $60 \mathrm{~d}$ postlesion.

A measure of binding to the high affinity KA receptor component is the difference between the total binding (in the absence of $\mathrm{Ca}^{2+}$ ) and binding in the presence of $\mathrm{Ca}^{2+}$ (Monaghan et al., 1986). When such calculations were made for binding (using 50 nM $\left.\left[{ }^{3} \mathrm{H}\right] \mathrm{KA}\right)$ in the ML at $60 \mathrm{~d}$ postlesion, an increase in the level of binding to the population of the high affinity sites was found. This increase was observed in the outer two-thirds of the ipsilateral ML. A strong tendency toward an increase in the binding was also observed in the inner one-third of the ipsilateral hippocampus. Since saturation analysis showed a lack of shift in the $K_{\mathrm{d}}$ of both the low affinity and mixed population of binding sites after the lesion, one can suggest that the increase in high affinity receptor binding reflects an increase in the number of these sites.

The observation of lesion-induced increases in high affinity binding in both the inner one-third and outer two-thirds of the $\mathrm{ML}$, while low affinity sites show a preferential increase in the outer two-thirds of the ML (Fig. 9), suggests the possibility of differential regulation of the high and low affinity KA binding sites. With the recent isolation of a cDNA clone that encodes the KA receptor (Hollmann et al., 1989), it should now be possible to examine lesion-induced changes in KA receptor mRNA. Furthermore, if the high and low affinity KA binding sites correspond to distinct receptor isoforms, it should be possible to examine their differential regulation in response to deafferentation and reactive sprouting.

The pattern of changes in hippocampal KA receptors following the loss of the entorhinal input differs from the time course of responses reported for NMDA and quisqualate receptors in the same experimental model (Ułas et al., 1990). The distinct responses of the various EAA receptors are evident especially during the early postlesion days: at this time point the binding levels of KA receptors in the deafferented ML on the operated side remain unchanged, whereas binding levels of quisqualate (and to a lesser degree, NMDA) receptors are diminished. Thirty to sixty days postlesion the KA, NMDA, and quisqualate receptors respond in a more uniform pattern. Elevated KA receptor levels in the ipsilateral ML are similar to those found for NMDA receptors in the outer two-thirds of the ipsilateral dentate gyrus ML; increases in the binding to quisqualate receptors are of smaller magnitude. Similar to quisqualate receptor binding, but in contrast to that of NMDA, changes in KA receptor binding are found only in the ipsilateral ML. This implies that although related to the same neurotransmitter(s), the EAA receptors in the ML of the hippocampus are differentially regulated in response to the loss of the entorhinal projection and to the subsequent circuit reorganization. This probably reflects the different roles they play in the physiology of the hippocampus.

Changes in the distribution profile of KA receptors observed in the ML of rat hippocampus at late time points after entorhinal lesions are similar to the changes in the distribution profile of KA receptors in the ML of Alzheimer's brain (Geddes et al., 1985; Geddes and Cotman, 1986). This is not surprising considering that in Alzheimer's disease the connections between the entorhinal cortex and the dentate gyrus are seriously damaged as a result of profound pathology of cells in the entorhinal area (Hyman et al., 1986). Although other studies (Cowburn et al., 1989) using membrane preparations from hippocampi of Alzheimer's brain failed to show changes in the number of KA receptors, this observation may be a consequence of using membranes prepared from the whole hippocampus instead of only from discrete layers of the dentate gyrus. It is interesting, however, that an increased density of KA receptors in the ML of the dentate gyrus has been found also in kindled rodents (Re- 
Ukas et al. • Hippocampal Kainate Receptors after Entorhinal Lesion

presa et al., 1989a) and in both temporal lobe (Geddes et al., 1990) and childhood epilepsy (Represa et al., 1989b), where the hippocampus did not show pathological changes.

The similar response to denervation of $\mathrm{KA}$ receptors in the rat hippocampus and in the Alzheimer's brain hippocampus implies that the rodent entorhinal lesion model may be valuable not only for studying the basic mechanisms of neuroplasticity, but also for understanding the pathological responses accompanying Alzheimer's disease.

\section{References}

Backus KH, Kettenmann H, Schachner M (1989) Pharmacological characterization of the glutamate receptor in cultured astrocytes. J Neurosci Res 22:274-282.

Bridges RJ, Nieto-Sampedro M, Kadri M, Cotman CW (1987) A novel chloride-dependent $\mathrm{L}-\left[{ }^{3} \mathrm{H}\right]$ glutamate binding site in astrocytes membranes. J Neurochem 48:1709-1715.

Cotman CW, Nadler JV (1978) Reactive synaptogenesis in the hippocampus. In: Neuronal plasticity (Cotman CW, ed), pp 227-276. New York: Raven.

Cotman CW, Nadler JV (1981) Glutamate and aspartate as hippocampal transmitters: biochemical and pharmacological evidence. In: Glutamate: transmitter in the central nervous system (Roberts JP, Storm-Mathisen J, Johnston GAR, eds), pp 117-154. New York: Wiley.

Cowburn RF, Hardy JA, Briggs RS, Roberts PJ (1989) Characterization, density, and distribution of kainate receptors in normal and Alzheimer's diseased human brain. J Neurochem 52:140-147.

Coyle JT (1983) Neurotoxic action of kainic acid. J Neurochem 41: $1-11$.

Fonnum F (1984) Glutamate: A neurotransmitter in mammalian brain. J Neurochem 42:1-11.

Foster AC, Mena EE, Monaghan DT, Cotman CW (1981) Synaptic localization of kainic acid binding sites. Nature 289:73-75.

Gage FH, Olejniczak P, Armstrong DM (1988) Astrocytes are important for sprouting in the septohippocampal circuit. Exp Neurol 102:2-13.

Geddes JW, Cotman CW (1986) Plasticity in hippocampal excitatory amino acid receptors in Alzheimer's disease. Neurosci Res 3:672678.

Geddes JW, Monaghan DT, Cotman CW, Lott IT, Kim RC, ChangChui H (1985) Plasticity of hippocampal circuitry in Alzheimer's disease. Science 230:1179-1181.

Geddes JW, Cahan LD, Cooper SM, Choi BH, Kim RC, Cotman CW (1990) Altered distribution of excitatory amino acid receptors in temporal lobe epilepsy. Exp. Neurology (in press).

Goldowitz D, White WF, Steward O, Cotman CW, Lynch G (1975) Anatomical evidence for a projection from the entorhinal cortex to the contralateral dentate gyrus of the rat. Exp Neurol 47:433-441.

Henke H, Beaudet A, Cuenod M (1981) Autoradiographic localization of specific kainic acid binding sites in pigeon and rat cerebellum. Brain Res 219:95-105.

Hoff SF, Scheff SW, Kwan AY, Cotman CW (1981) A new type of lesion-induced synaptogenesis. I. Synaptic turnover in nondenervated zones of the dentate gyrus in young adult rats. Brain Res 222:1-13.

Hoff SF, Scheff SW, Cotman CW (1982a) Lesion-induced synaptogenesis in the dentate gyrus of aged rats. II. Demonstration of an impaired degeneration clearing response. J Comp Neurol 205:253259.

Hoff SF, Scheff SW, Benardo LS, Cotman CW (1982b) Lesion-induced synaptogenesis in the dentate gyrus of aged rats. I. Loss and reacquisition of normal synaptic density. J Comp Neurol 205:246-252.

Hollmann M, O'Shea-Greenfield A, Rogers SW, Heinemann S (1989) Cloning by functional expression of a member of the glutamate receptor family. Nature 342:643-648.

Honoré T, Drejer J, Nielsen M (1986) Calcium discriminates two $\left[{ }^{3} \mathrm{H}\right]$ kainate binding sites with different molecular target sizes in rat cortex. Neurosci Lett 65:47-52.
Hyman BT, Van Hoesen GW, Kromer LJ, Damasio AR (1986) Perforant pathway changes and the memory impairment of Alzheimer's disease. Ann Neurol 20:472-481.

Lynch G, Stanfield B, Cotman CW (1973) Developmental differences in post-lesion axonal growth in the hippocampus. Brain Res 59:155168.

Lynch G, Rose G, Gall C, Cotman CW (1975) The response of the dentate gyrus to partial deafferentation. In: The Golgi Centennial Symposiun (Santini R, ed), pp 303-317. New York: Raven.

Lynch G, Gall C, Rose G, Cotman C (1976) Changes in the distribution of the dentate gyrus associational system following unilateral or bilateral entorhinal lesions in the adult rat. Brain Res 110:57-71.

Lynch G, Gall C, Cotman CW (1977) Temporal parameters of axon "sprouting" in the brain of the adult rat. Exp Neurol 54:179-183.

McPherson GA (1985) Kinetic, EBDA, Ligand, Lowry. A collection of radioligand binding analysis programs. Cambridge, UK: ElsevierBIOSOFT.

Monaghan DT, Cotman CW (1982) Distribution of $\left[{ }^{3} \mathrm{H}\right]$ kainic binding sites in rat CNS as determined by autoradiography. Brain Res 252 91-100.

Monaghan DT, Mena EE, Cotman CW (1982) The effect of entorhinal cortical ablation on the distribution of muscarinic cholinergic receptors in the rat hippocampus. Brain Res 234:480-485.

Monaghan DT, Yao D, Cotman CW (1985) L- $\left[{ }^{3} \mathrm{H}\right]$ Glutamate binds to kainate-, NMDA- and AMPA-sensitive binding sites: an autoradiographic analysis. Brain Res 340:378-383.

Monaghan DT, Nguyen L, Cotman CW (1986) The distribution of $\left[{ }^{3} \mathrm{H}\right]$ kainate binding sites in primate hippocampus is similar to the distribution of both $\mathrm{Ca}^{2+}$-sensitive and $\mathrm{Ca}^{2+}$-insensitive $\left[{ }^{3} \mathrm{H}\right] \mathrm{kainate}$ binding sites in rat hippocampus. Neurochem Res 11:1073-1082.

Naik NT (1963) Technical variations on Koelle's histochemical method for demonstrating cholinesterase activity. Q J Microsc Sci 104: 89-100.

Olney JW, Rhee V, Ho L (1974) Kainic acid: a powerful neurotoxic analogue of glutamate. Brain Res 77:507-512.

Represa A, Le Gall La Salle G, Ben-Ari Y (1989a) Hippocampal plasticity in the kindling model of epilepsy in rats. Neurosci Lett 99: $345-350$

Represa A, Robain O, Tremblay E, Ben-Ari Y (1989b) Hippocampal plasticity in childhood epilepsy. Neurosci Lett 99:351-355.

Rose G, Lynch G, Cotman CW (1976) Hypertrophy and redistribution of astrocytes in the deafferented dentate gyrus. Brain Res Bull 1:8792.

Scheff SW, Bernardo LS, Cotman CW (1980) Decline in reactive fiber growth in the dentate gyrus of aged rats compared to young adult rats following entorhinal cortex removal. Brain Res 199:21-38.

Steward O, Vinsant SL (1983) The process of reinnervation in the dentate gyrus of the adult rat: $\Lambda$ quantitative electron microscopic analysis of terminal proliferation and reactive synaptogenesis. J Comp Neurol 214:370-386.

Tremblay E, Represa A, Ben-Ari Y (1985) Autoradiographic localisation of kainic acid binding sites in the human hippocampus. Brain Res 343:378-382

Ukas J, Monaghan DT, Cotman CW (1990) Plastic response of hippocampal excitatory amino acid receptors to deafferentation and reinnervation. Neuroscience 34:9-17.

Unnerstall JR, Wamsley JK (1983) Autoradiographic localization of high-affinity $\left[{ }^{3} \mathrm{H}\right]$ kainic acid binding sites in the rat forebrain. Eur $\mathrm{J}$ Pharmacol 86:361-371

Vijayan V, Cotman CW (1983) Lysosomal enzyme changes in young and aged control and entorhinal-lesioned rats. Neurobiol Aging 4:1323.

White WF, Nadler JV, Hamberger A, Cotman CW, Cummins JT (1977) Glutamate as transmitter of hippocampal perforant path. Nature 270: 356-357.

Zimmer J (1973) Extended commissural and ipsilateral projections in postnatally deentorhinated hippocampus and fascia dentata, demonstrated in rats by silver impregnation. Brain Kes 64:293-311.

Zimmer J, Hjorth-Simonsen A (1975) Crossed pathways from the entorhinal area to the fascia dentata. II. Provokable in rats. J Comp Neurol 161:71-102. 